\title{
DESKRIPSI PENGETAHUAN DASAR MATEMATIKA SISWA mSMP NEGERI 1 NAPABALANO
}

\author{
Anwar ${ }^{1}$, Faad Maonde ${ }^{2}$, La Masi, \\ ( ${ }^{1}$ Mahasiswa Jurusan Pendidikan Matematika, ${ }^{2,3}$ Dosen Jurusan Pendidikan Matematika FKIP \\ Universitas Halu Oleo) email: anwarmtk13@gmail.com; faadmaonde@yahoo,.com; \\ lamasimbahido1966@yahoo.co.id;
}

\begin{abstract}
Abstrak
Penelitian ini bertujuan untuk mengetahui deskripsi pengetahuan dasar matematika siswa SMP Negeri 1 Napabalano. Populasi dalam penelitian ini adalah siswa SMP Negeri 1 Napabalano. Pengambilan sampel adalah quota sampling. Pengambilan data TPDM diperoleh rata-ratanya sebesar 55,23, median sebesar 56, modus sebesar 56, standar deviasinya sebesar 11,52, varians sebesar 132,78 dan persentase perolehan nilai siswa termasuk kategori rendah sebesar $57,59 \%$. Rata-rata untuk siswa kelas VII sebesar 54,28, median sebesar 52, modus sebesar 48, standar deviasinya sebesar 11,31, varians sebesar 127,82 dan persentase perolehan nilai siswa termasuk kategori rendah sebesar 60,89\%. Rata-rata untuk siswa kelas VIII sebesar 56,65, median sebesar 60, modus sebesar 40, standar deviasinya sebesar 12,38, varians sebesar 153,33 dan persentase perolehan nilai siswa termasuk kategori sedang sebesar 50,62\%. Rata-rata untuk siswa kelas IX sebesar 54,57, median sebesar 56, modus sebesar 56, standar deviasinya sebesar 10,78 dan varians sebesar 116,11 dan persentase perolehan nilai siswa termasuk kategori rendah sebesar $63,03 \%$.
\end{abstract}

Kata Kunci: Tes Pengetahuan Dasar Matematika, kategori rendah, quota sampling

\section{DESCRIPTION BASIC KNOWLEDGE MATHEMATICS STUDENTS SMP NEGERI 1 NAPABALANO}

\begin{abstract}
This study aims to determine the description of basic knowledge of mathematics students of SMP Negeri 1 Napabalano. The population in this study were students of SMP Negeri 1 Napabalano. Sampling is quota sampling. TPDM data retrieval was averaged 55.23, the median was 56 , the mode was 56, the standard deviation of 11.52 , the variance of 132.78 and the percentage of the score of the students included the low category of $57.59 \%$. The average for Grade VII students is 54.28 , the median is 52 , the mode is 48 , the standard deviation is 11.31 , the variance is 127.82 and the percentage of the students achievement is the low category of $60.89 \%$. The average for grade VIII students is 56.65 , the median is 60 , the mode is 40 , the standard deviation is 12.38 , the variance is 153.33 and the percentage of the students score is medium category $50,62 \%$. The average for grade IX students is 54.57 , the median is 56 , the mode is 56 , the standard deviation is 10.78 and the variance is 116.11 and the percentage of the students score is $63.03 \%$ low.
\end{abstract}

Keywords: Basic Mathematics Knowledge Test, the low category, quota sampling 


\section{Pendahuluan}

Menurut jenjang keilmuannya statistika dibedakan menjadi dua, yaitu statistika deskripsi dan statistika inferensial. Statistika deskripsi sering disebut sebagai statistika deduktif yang membahas tentang bagaimana merangkum sekumpulan data dalam bentuk yang mudah dibaca dan cepat memberikan informasi, yang disajikan dalam bentuk tabel, grafik, nilai pemusatan dan nilai penyebaran. Hasan (2002: 17) menyatakan statistik deskripsi adalah bagian dari statistika yang mempelajari cara pengumpulan data dan penyajian data sehingga mudah dipahami. Statistika deskripsi hanya berhubungan dengan hal menguraikan atau memberikan keterangan-keterangan mengenai suatu data atau keadaan. Dengan kata lain statistika deskripsi berfungsi menerangkan keadaan, gejala, atau persoalan. Penarikan kesimpulan pada statistika deskripsi (jika ada) hanya ditujukan pada kumpulan data yang ada.

Berbicara tentang analisis deskripsi berarti menggambarkan data yang sudah dikumpulkan. Sugiyono (2004: 169) menyatakan analisis deskripsi adalah statistik yang digunakan untuk menganalisa data dengan cara mendeskripsikan atau menggambarkan data yang telah terkumpul sebagaimana adanya tanpa bermaksud membuat kesimpulan yang berlaku untuk umum atau generalisasi.

Belajar adalah sesuatu yang lumrah atau wajib bagi seorang individu yang ingin mengetahui sesuatu. Sebagian besar dari proses perkembangan berlangsung melalui kegiatan belajar. Sardiman dalam Faticha (2015: 9) belajar adalah perubahan tingkah laku yang relatif mantap berkat latihan dan pengalaman. Belajar bukan menghafal dan bukan mengingat. Belajar adalah suatu proses yang ditandai dengan adanya perubahan pada diri seseorang. Belajar adalah kegiatan yang berproses dan merupakan unsur yang sangat fundamental dalam setiap penyelenggaraan jenis dan jenjang pendidikan.

Pembelajaran adalah proses interaksi dalam proses belajar antara guru dan siswa. Rusman dalam Nismawati (2017: 8) menyatakan pembelajaran merupakan suatu sistem, yang terdiri dari berbagai komponen yang saling berhubungan satu dengan yang lain. Komponen tersebut meliputi: tujuan, materi, metode dan evaluasi. Pembelajaran pada hakikatnya merupakan proses interaksi antara guru dengan siswa, baik interaksi secara langsung seperti kegiatan tatap muka maupun secara tidak langsung, yaitu dengan berbagai media pembelajaran.

Matematika adalah cabang ilmu yang mempelajari penalaran dan struktur yang logis tentang bilangan. Soedjadi (2000: 11) menyatakan definisi matematika, yaitu: (1) matematika adalah cabang pengetahuan eksak dan terorganisasi secara sistematis. (2) Matematika adalah pengetahuan tentang bilangan dan kalkulasi. (3) Matematika adalah pengetahuan tentang penalaran logis dan berhubungan dengan bilangan. (4) Matematika adalah pengetahuan tentang fakta-fakta kuantitatif dan masalah ruang dan bentuk. (5) Matematika adalah pengetahuan tentang struktur-struktur yang logis. (6) Matematika adalah pengetahuan tentang aturan yang ketat.

Pengetahuan adalah sesuatu yang didapatkan setelah seseorang melakukan suatu aktivitas seperti melihat, mendengar, merasakan dan lain sebagainya. Sebagian besar pengetahuan dapat diperoleh dari melihat dan mendengar. Banyak contoh dalam kehidupan kita sehari-hari yang dapat kita jadikan suatu pengetahuan. Hanya dengan melihat seorang individu dapat mengetahui sesuatu yang baru yang belum diketahui sebelum. Jadi, pengetahuan merupakan segala sesuatu yang mencakup apa yang sudah diketahui.

Pengetahuan itu sendiri dipengaruhi oleh faktor pendidikan formal. Orang-orang belajar dengan cara mengembangkan pengetahuan yang telah dimiliki. Sangatlah penting untuk mengembangkan kegiatan pendidikan yang relevan dengan pengetahuan yang telah dimiliki oleh siswa sehingga mereka dapat belajar dengan baik. Dalam Wawan dan Dewi (2010: 12) pengetahuan sangat erat hubungannya dengan pendidikan, dimana diharapkan bahwa dengan pendidikan yang tinggi maka orang tersebut akan semakin luas pula pengetahuannya. Akan tetapi perlu ditekankan, bukan berarti seseorang yang berpendidikan rendah mutlak berpengetahuan rendah pula. Pengetahuan seseorang tentang suatu objek mengandung dua aspek, yaitu aspek positif dan negatif. Kedua aspek ini yang akan menentukan sikap seseorang semakin banyak aspek positif dan objek yang diketahui, maka akan menimbulkan sikap makin positif terhadap objek tertentu. 
Pengetahuan dasar yang dimiliki oleh seorang siswa mempunyai peranan penting dalam pembelajarannya. Mahdaniah (2016: 2) menyatakan siswa yang mempunyai kemampuan tinggi dan pengetahuan dasar matematika yang di atas rata-rata akan dengan mudah menerima pelajaran yang akan diberikan oleh guru. Sebaliknya bagi siswa yang mempunyai pengetahuan dasar matematika di bawah rata-rata akan sulit menerima pelajaran yang akan diberikan oleh guru yang terkait dengan pelajaran dimasa lalunya. Dalam pembelajaran matematika tingkat Sekolah Menengah Pertama (SMP) siswa sudah harus mempunyai dasar pembelajaran dari tingkat sebelumnya atau tingkat Sekolah Dasar (SD), sedangkan untuk materi pelajaran matematika ditingkat Sekolah Menengah Atas (SMA) siswa sudah harus mempunyai pengetahuan dasar yang bagus untuk materi tingkat Sekolah Menengah Pertama (SMP) dan Sekolah Dasar (SD), hal ini mengisyaratkan bahwa matematika merupakan ilmu yang memiliki keterkaitan antara pengetahuan dasar untuk melanjutkan pendidikan ditingkat selanjutnya.

Pengetahuan dasar yang menjadi acuan dari ilmu-ilmu yang lain adalah pengetahuan dasar matematika, dalam Muliani (2016: 2) mengingat matematika merupakan ilmu dasar bagi disiplin ilmu yang lain sekaligus sebagai sarana yang melatih siswa berpikir kritis dan logis. Matematika merupakan mata pelajaran yang diajarkan dari jenjang pendidikan dasar sampai menengah. Selain mempunyai sifat yang abstrak, pemahaman konsep matematika yang baik sangatlah penting karena untuk memahami konsep yang baru diperlukan prasyarat pemahaman konsep sebelumnya. Sampai saat ini masih banyak ditemui kesulitan siswa untuk mempelajari matematika dan masih rendahnya hasil belajar matematika.

Pengetahuan dasar matematika adalah pengetahuan awal matematika yang menjadi dasar atau acuan ilmu matematika siswa untuk menyelesaikan materi-materi matematika yang lebih kompleks. Maonde (2011: 106) menyatakan kemampuan mengingat pembelajaran pengetahuan dasar matematika adalah kemampuan siswa mengingat materi pelajaran matematika yang pernah dipelajarinya dimasa lalu dan menjadikannya sebagai dasar untuk mempermudah menerapkan dan menghubungkannya dengan materi pelajaran selanjutnya.
Kurang aktifnya siswa dalam proses pembelajaran matematika siswa SMP masih menjadi keluhan guru pada SMP Negeri 1 Napabalano. Pengetahuan dasar matematika yang masih belum tuntas merupakan faktor yang menyebabkan rendahnya prestasi belajar matematika siswa tersebut. Hal ini disebabkan siswa tidak atau kurang menguasai materimateri dasar matematika yang seharusnya telah dituntaskan di jenjang sebelumnya. Seperti materi bilangan bulat, KPK dan FPB, pecahan dan lain-lain yang semestinya sudah dikuasai di Sekolah Dasar (SD). Halistin (2014: 3-4) menyatakan bahwa penguasaan yang kurang pada materi dasar matematika tersebut berakibat pada kesulitan siswa dalam memahami materi matematika berikutnya dan akan berdampak pada rendahnya prestasi belajar matematika. Matematika tersusun secara hierarkis, konsep yang satu menjadi dasar untuk mempelajari konsep selanjutnya. Sifat ini menyebabkan penguasaan matematika siswa pada proses pembelajaran dipengaruhi oleh kemampuannya menguasai konsep matematika sebelumnya. Misalnya, sebelum mempelajari operasi bentuk aljabar, siswa terlebih dahulu harus memahami konsep operasi bilangan bulat, sebelum mempelajari konsep volume pada bangun ruang, siswa terlebih dahulu harus memahami konsep luas pada bangun datar. Artinya, untuk dapat meningkatkan kemampuan matematika siswa, pengetahuan dasar matematika merupakan faktor yang sangat mempengaruhi. Sayangnya, salah satu fakta yang ditemukan di lapangan bahwa masih terdapat siswa SMP yang belum menguasai konsep operasi bilangan bulat, padahal konsep ini seharusnya telah dikuasai sebelum siswa memasuki jenjang SMP.

Penting bagi seorang guru untuk mengetahui kesiapan siswa dalam menerima materi yang akan disampaikan di kelas. Salah satu kesiapan siswa yang harus diperiksa oleh guru adalah penguasaan siswa terhadap materimateri dasar matematika yang menunjang materi-materi yang akan diajarkan atau PDM siswa. Karena dengan mengetahui PDM siswanya, seorang guru dapat merancang proses pembelajaran seperti apa yang cocok untuk diterapkannya di kelas sehingga akan memberi hasil belajar yang lebih optimal. Oleh karena itu, konsep-konsep matematika harus dikuasai oleh siswa mulai dari pengetahuan dasar. Pengetahuan dasar matematika yang dimiliki oleh seorang siswa yang mempunyai 
kemampuan tinggi dan pengetahuan dasar matematika yang baik akan dengan mudah menerima pelajaran yang akan diberikan oleh guru. Pendidik berharap siswa akan lebih siap untuk belajar dari pelajaran berikutnya, kelas berikutnya, tahun berikutnya dan kesempatan yang ada. Penguasaan terhadap materi materimateri dasar matematika inilah yang dimaksud dengan pengetahuan dasar matematika. Sehingga tujuan pembelajaran dapat tercapai sesuai dengan yang diharapkan.

Berdasarkan uraian latar belakang di atas peneliti mangambil judul penelitian tentang
"Deskripsi Pengetahuan Dasar Matematika Siswa Di SMP Negeri 1 Napabalano".

\section{Metode}

Jenis penelitian ini adalah penelitian deskriptif dengan perolehan data menggunakan deskriptif kuantitatif. Tempat dan waktu penelitian ini dilaksanakan di SMP Negeri 1 Napabalano pada semester genap tahun 2017/2018. Populasi dalam penelitian ini adalah seluruh siswa kelas VII, VIII, IX SMP Negeri 1 Napabalano.

Tabel 1.

Populasi Penelitian

\begin{tabular}{|c|c|c|c|c|c|c|}
\hline \multirow{2}{*}{ No } & \multirow{2}{*}{ Nama Sekolah } & Nilai Akreditasi & \multirow{2}{*}{$\begin{array}{c}\text { Jumlah } \\
\text { siswa }\end{array}$} & & \multicolumn{3}{|c|}{ Kelas } \\
\cline { 5 - 7 } & & & & VII & VIII & IX \\
\hline 1 & SMPN 1 Napabalano & A & 526 & 173 & 174 & 179 \\
\hline
\end{tabular}

Sampel adalah bagian terpadu dari jumlah dan karakteristik yang dimiliki oleh populasi tersebut adalah kelas VII, VIII, IX SMP Negeri 1 Napabalano. Bila populasi besar peneliti tidak memungkinkan untuk mempelajari semua populasi dikarenakan adanya keterbatasan waktu dan tenaga, maka peneliti dapat menggunakan sampel yang diambil dari populasi itu. Untuk itu, sampel yang diambil

dari populasi harus betul-betul representatif (mewakili ciri dari populasi). Karena populasi dalam penelitian ini cukup terjangkau untukmenjadikan semua siswa sebagai sampel penelitian sehingga dapat dikatakan sampel yang digunakan adalah quota sampling.

Tabel 2.

Sampel Penelitian

\begin{tabular}{c|c|c|c|c|c|c|c|}
\hline \multirow{2}{*}{ No } & Nama Sekolah & Nilai Akreditasi & \multirow{2}{*}{$\begin{array}{c}\text { Jumlah } \\
\text { siswa }\end{array}$} & \multicolumn{3}{|c|}{ Kelas } \\
\cline { 5 - 7 } & & & & VII & VIII & IX \\
\hline 1 & SMPN 1 Napabalano & A & 526 & 173 & 174 & 179 \\
\hline \\
Teknik pengumpulan data dalam
\end{tabular}
tes merupakan cara pengumpulan data dalam bentuk sejumlah pernyataan tertulis yang digunakan untuk memperoleh infomasi dari responden dalam arti laporan kepribadianya atau dalam hal-hal yang diketahuinya. Dalam hal ini, tes-tes yang digunakan adalah tes pengetahuan dasar matematika (TPDM) yang digunakan untuk mengukur pengetahuan dasar matematika siswa SMP Negeri 1 Napabalano. Soal ini berbentuk pilihan ganda. Hasil pekerjaan siswa akan dikumpulkan oleh peneliti untuk diperiksa dan diberi skor, benar bernilai 1, salah bernilai 0 . Skor perolehan siswa kemudian dikonversi ke skala 100 dengan aturan:
Kriteria nilai perolehan siswa tersebut menurut Depdikbud dalam Halistin (2014: 27) yaitu sebagai berikut:

Hasil tes tinggi jika $80 \leq \mathrm{Y} \leq 100$

Hasil tes sedang jika $60 \leq Y<80$

Hasil tes rendah jika $Y<60$

Dimana Y adalah nilai perolehan siswa pengetahuan dasar matematika siswa.

Analisis data dalam penelitian ini adalah data kuantitatif yang diperoleh melalui nilai siswa pada hasil tes pengetahuan dasar matematika. Nilai siswa tersebut dianalisis dan dideskripsikan dengan mencari nilai rata-rata, 
median, modus dan standar deviasinya serta varians.

\section{Hasil}

Analisis dalam penelitian ini mencakup hal-hal sebagai berikut, yaitu : (i) Analisis Validitas dan Reliabilitas melalui penilaian panelis, (ii) Analisis deskriptif hasil Tes Pengetahuan Dasar Matematika.
Dari 25 butir soal yang diajukan melalui panelis, berdasarkan kriteria yang diberikan, diperoleh 25 butir soal valid atau semua soal yang diajukan valid. Dengan koefisien reliabilitas $\left(r_{i i}\right)$ sebesar $0,99406 \geq 0,70 \quad$, maka tes untuk Pengetahuan Dasar Matematika dari 25 butir soal tersebut memiliki konsistensi yang tinggi. Dengan kata lain, tes dibuat tersebut memiliki kualitas yang baik dilihat dari koefisien reliabilitas.

Tabel 3.

Deskriptif Hasil Tes Pengetahuan Dasar Matematika Siswa

\begin{tabular}{|l|c|c|c|c|c|c|c|c|}
\hline \multicolumn{1}{|c|}{ Siswa } & $\begin{array}{c}\text { Jumlah } \\
\text { Siswa }\end{array}$ & Min & Max & $\begin{array}{c}\text { Rata- } \\
\text { Rata }\end{array}$ & Median & Modus & $\begin{array}{c}\text { Standar } \\
\text { Deviasi }\end{array}$ & Varians \\
\hline $\begin{array}{l}\text { SMP N 1 } \\
\text { Napabalano }\end{array}$ & 526 & 20 & 92 & 55,23 & 56 & 48 & 11,52 & 132,78 \\
\hline Kelas VII & 173 & 28 & 88 & 54,28 & 52 & 48 & 11,3 & 127,82 \\
\hline Kelas VIII & 174 & 20 & 80 & 56,65 & 60 & 40 & 12,38 & 153,33 \\
\hline Kelas IX & 179 & 20 & 92 & 54,75 & 56 & 56 & 10,77 & 116,11 \\
\hline
\end{tabular}

Berdasarkan tabel 3 gambaran nilai yang diperoleh siswa hasil Tes Pengetahuan Dasar Matematika di SMP Negeri 1 Napabalano untuk tiap nilai minimum, maksimum, rata-rata, median, modus, standar deviasi dan varians bisa dibuatkan dalam bentuk grafik boxplot untuk tiap jenjang kelasnya. Untuk grafik boxplot dapat dilihat pada grafik 1 berikut.

\section{Grafik 1}

Deskripsi Hasil TPDM Siswa SMP Negeri 1 Napabalano

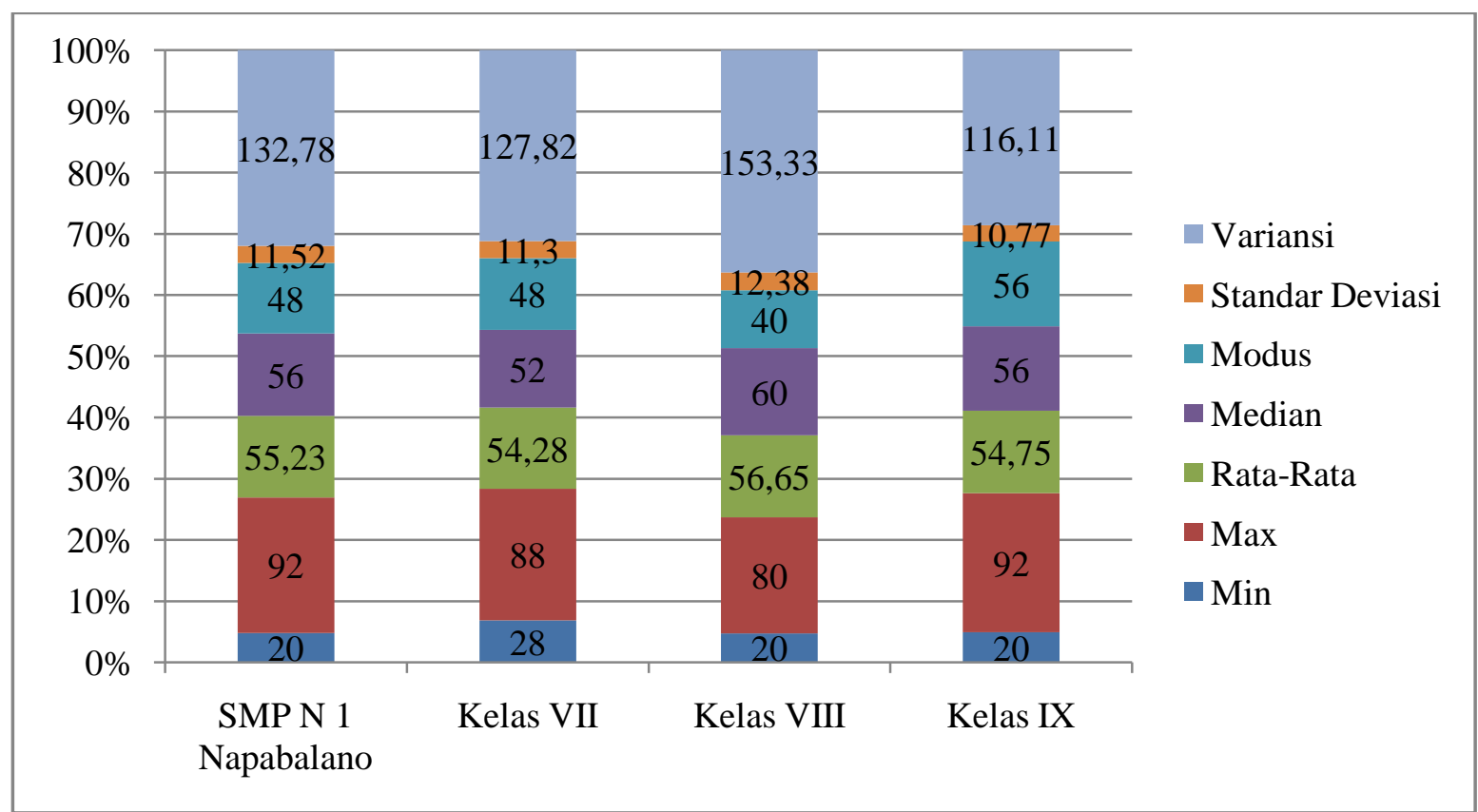

Berdasarkan tabel 3, nilai minimum dan maksimum hasil Tes Pengetahuan Dasar Matematika siswa kelas VII, VIII dan IX SMP Negeri 1 Napabalano untuk keseluruhan terlihat nilai maksimum dari perolehan nilai siswa yaitu sebesar 92, termasuk kategori tinggi karena berada pada interval $80 \leq$ nilai siswa $\geq 100$. Nilai maksimum perolehan siswa untuk kelas VII sebesar 88 termasuk kategori tinggi. Nilai maksimum perolehan siswa pada kelas VIII 
sebesar 80 termasuk kategori tinggi. Nilai maksimum perolehan siswa untuk kelas IX sebesar 92 termasuk kategori tinggi. Untuk nilai minimum secara keseluruhan dari perolehan nilai siswa yaitu sebesar 20, termasuk kategori rendah karena berada pada interval nilai siswa < 60. Nilai minimum perolehan siswa untuk kelas VII sebesar 28 termasuk kategori rendah. Nilai minimum perolehan siswa pada kelas VIII sebesar 20 termasuk kategori rendah. Nilai minimum perolehan siswa untuk kelas IX sebesar 20 termasuk kategori rendah.

Nilai rata-rata hasil Tes Pengetahuan Dasar Matematika siswa kelas VII, VIII dan IX SMP Negeri 1 Napabalano untuk keseluruhan terlihat bahwa rata-ratanya sebesar 55,23. Jika dilihat rata-rata perjenjang kelasnya diperoleh nilai rata-rata hasil TPDM siswa pada kelas VII yaitu 54,28 dan rata-rata kelas VIII sebesar 56,65 serta rata-rata kelas IX yakni 54,75. Hal ini menunjukkan perolehan nilai rata-rata siswa pada kelas VIII sebesar 56,29 lebih besar dari rata-rata nilai siswa pada kelas VII dan kelas IX dan perolehan rata-rata siswa kelas IX lebih besar dari siswa kelas VII.

Nilai median atau data tengah hasil Tes Pengetahuan Dasar Matematika siswa SMP Negeri 1 Napabalano terlihat bahwa mediannya sebesar 56, termasuk kategori rendah karena berada pada interval nilai siswa $<60$. Jika dilihat dari median perjenjang kelasnya diperoleh nilai median hasil Tes Pengetahuan Dasar Matematika siswa pada kelas VII yaitu sebesar 52 termasuk kategori rendah. Nilai median untuk kelas VIII yaitu sebesar 60 termasuk kategori sedang. Nilai median untuk kelas IX yaitu sebesar 56 termasuk kategori rendah.

Nilai modus atau frekuensi nilai yang sering muncul hasil Tes Pengetahuan Dasar Matematika siswa kelas VII, VIII dan IX SMP Negeri 1 Napabalano untuk keseluruhan terlihat bahwa modusnya sebesar 56, termasuk kategori rendah karena berada pada interval nilai siswa < 60. Jika dilihat dari modus perjenjang kelasnya diperoleh nilai modus hasil Tes Pengetahuan Dasar Matematika siswa pada kelas VII yaitu sebesar 48 termasuk kategori rendah. Nilai modus untuk kelas VIII yaitu sebesar 40 termasuk kategori rendah. Nilai modus untuk kelas IX yaitu sebesar 56 termasuk kategori rendah. Sehingga dapat dikatakan bahwa setelah dilihat modus perjenjangnya semua berada pada kategori rendah begitupula jika dilihat secara keseluruhan nilai modusnya berada dalam kategori rendah.

Hubungan antara nilai rata-rata, median dan modus adalah jika rata-rata, median dan modus memiliki nilai yang sama, maka nilai rata-rata, median dan modus akan terletak pada satu titik. Kurva distribusi frekuensi tersebut akan terbentuk simetris. Jika rata-rata lebih besar dari median, dan median lebih besar dari modus, maka pada kurva distribusi frekuensi, nilai rata-rata akan terletak di sebelah kanan, sedangkan median terletak di tengahnya dan modus di sebelah kiri. Kurva distribusi frekuensi yang terbentuk adalah mencengkanan atau kemencengan positif. Jika rata-rata lebih kecil dari median, dan median lebih kecil dari modus, maka pada kurva distribusi frekuensi, nilai ratarata akan terletak di sebelah kiri, sedangkan median terletak ditengahnya dan modus di sebelah kanan. Kurva distribusi frekuensi yang terbentuk adalah menceng kiri atau kemencengan negatif. Berdasarkan hasil Tes Pengetahuan Dasar Matematika Siswa SMP Negeri 1 Napabalano nilai rata-rata sebesar 55,23 sehingga lebih kecil dari nilai median yaitu 56, dan nilai median lebih besar dari nilai modus sebesar 48 . Untuk tiap jenjangnya kelas VII memiliki nilai rata-rata sebesar 54,28 sehingga lebih besar dari nilai median yaitu 52 dan nilai median lebih besar dari nilai modus sebesar 48, maka pada kurva distribusi frekuensi, nilai rata-rata akan terletak di sebelah kanan, sedangkan median terletak di tengahnya dan modus di sebelah kiri. Kurva distribusi frekuensi yang terbentuk adalah mencengkanan atau kemencengan positif. Kelas VIII memiliki nilai rata-rata sebesar 56,65 sehingga lebih kecil dari nilai median yaitu 60 dan nilai median lebih besar dari nilai modus sebesar 40. Kelas IX memiliki nilai rata-rata sebesar 54,75 sehingga lebih kecil dari nilai median yaitu 56 dan nilai median sama dengan nilai modus.

Nilai standar deviasi hasil Tes Pengetahuan Dasar Matematika siswa SMP Negeri 1 Napabalano terlihat bahwa standar deviasinya sebesar 11,52. Jika dilihat berdasarkan jenjang kelas nilai standar deviasi untuk kelas VII sebesar 11,31, kelas VIII sebesar 12,38 dan kelas IX sebesar 10,78. Jika diperhatikan nilai standar deviasi untuk jenjang kelas yang nilai standar deviasi paling tinggi diperoleh kelas VIII dan standar deviasi paling rendah diperoleh kelas IX. Jika dihubungkan 
dengan nilai rata-rata untuk masing-masing jenjang kelasnya jika standar deviasi terendah maka semakin mendekati rata-rata, sedangkan jika nilai standar deviasi semakin tinggi maka semakin lebar rentang variasi datanya. Jadi untuk kelas IX yang mempunyai standar deviasi terendah diantara kelas VII dan kelas VIII sehingga memiliki sebaran data lebih mendekati nilai rata-ratanya. Nilai varians hasil Tes Pengetahuan Dasar Matematika siswa SMP Negeri 1 Napabalano terlihat bahwa variansnya sebesar 132,78 dan nilai varians ini besar sehingga data yang dimiliki beragam. Jika dilihat berdasarkan jenjang kelas nilai varians untuk kelas VII sebesar 127,82, kelas VIII sebesar 153,33 dan kelas IX sebesar 116,11. Karena varians adalah ukuran keberagaman data, sehingga semakin besar nilai varians maka semakin beragamlah data yang kita miliki dan semakin kecil nilai varians yang kita miliki maka semakin homogenlah data yang kita miliki. Sehingga berdasarkan data nilai varians yang diperoleh dapat dikatakan bahwa data yang dimiliki beragam.

Berdasarkan kategori soal C1 sampai C6 Tes Pengetahuan Dasar Matematika Siswa SMP Negeri 1 Napabalano

Tabel 4.

Persentase Hasil TPDM Siswa SMP Negeri 1 Napabalano Dengan Kategori Soal C1 Sampai C6

\begin{tabular}{|c|l|c|c|c|c|c|c|}
\hline \multirow{2}{*}{ No. } & \multirow{2}{*}{ Siswa } & \multicolumn{5}{|c|}{ Persentase Tiap Kategori Soal Hasil TPDM } \\
\cline { 3 - 8 } & & C1 & C2 & C3 & C4 & C5 & C6 \\
\hline 1 & SMP Negeri 1 Napabalano & 54,64 & 41,9 & 92,96 & 56,08 & 12,48 & 7,76 \\
\hline 2 & Kelas VII & 17,44 & 13,44 & 32,2 & 16,44 & 3,32 & 1,88 \\
\hline 3 & Kelas VIII & 18,4 & 14,16 & 30 & 19,88 & 5,12 & 3,24 \\
\hline 4 & Kelas IX & 18,8 & 14,3 & 30,76 & 19,76 & 4,04 & 2,64 \\
\hline
\end{tabular}

Berdasarkan tabel 4 dapat dilihat bahwa pada kategori soal C1 sampai C6 secara keseluruhan yang memperoleh persentase tertinggi adalah terdapat pada kategori soal C3 dengan persentase sebesar 92,96\%. Kemudian secara berturut-turut dari urutan tertinggi yaitu kategori soal $\mathrm{C} 1$ sebesar 54,64 \%, kategori soal C4 sebesar 65,08 \%, kategori soal C2 sebesar $41,9 \%$, kategori soal C5 sebesar 12,48 \% dan kategori soal C6 sebesar 7,76 \%. Jika dilihat berdasarkan tiap jenjangnya dimulai dari kelas VII, untuk persentase tertinggi diperoleh kategori soal C3 dengan persentase sebesar 32,2 $\%$. Kemudian secara berturut-turut dari urutan tertinggi yaitu kategori soal C1 sebesar 17,44 \%, kategori soal C4 sebesar $16,44 \%$, kategori soal C2 sebesar 13,44\%, kategori soal C5 sebesar 3,32 \% dan kategori soal C6 sebesar 1,88\%.

diperoleh kategori soal C3 dengan persentase sebesar $30 \%$. Kemudian secara berturut-turut dari urutan tertinggi yaitu kategori soal $\mathrm{C} 4$ sebesar 19,88\%, kategori soal C1 sebesar 18,4 $\%$, kategori soal C2 sebesar 14,16\%, kategori soal C5 sebesar 5,12 \% dan kategori soal C6 sebesar 3,24\%. Pada kelas IX, untuk persentase tertinggi diperoleh kategori soal C3 dengan persentase sebesar 30,76\%. Kemudian secara berturut-turut dari urutan tertinggi yaitu kategori soal C4 sebesar 19,76\%, kategori soal C1 sebesar 18,8 \%, kategori soal C2 sebesar 14,3 $\%$, kategori soal C5 sebesar 4,04\% dan kategori soal C6 sebesar 2,64\%.

Berdasarkan nilai persentase hasil Tes Pengetahuan Dasar Matematika Siswa SMP Negeri 1 Napabalano

Tabel 5.

Persentase Hasil TPDM Siswa SMP Negeri 1 Napabalano

\begin{tabular}{|c|c|c|c|c|}
\hline Interval & Kategori & $\begin{array}{l}\text { Banyaknya Siswa } \\
\text { Yang Tes (Orang) }\end{array}$ & $\begin{array}{c}\text { Jumlah Siswa Dalam } \\
\text { Interval (Orang) }\end{array}$ & $\begin{array}{l}\text { Persentase } \\
\text { Siswa (\%) }\end{array}$ \\
\hline $80 \leq y \leq 100$ & Tinggi & \multirow{3}{*}{481} & 4 & 0,83 \\
\hline $60 \leq y<80$ & Sedang & & 200 & 41,58 \\
\hline$y<60$ & Rendah & & 277 & 57,58 \\
\hline
\end{tabular}


Berdasarkan tabel persentase nilai siswa dari hasil Tes Pengetahuan Dasar Matematika siswa SMP Negeri 1 Napabalano bahwa untuk keseluruhan perolehan nilai siswa yang melaksanakan TPDM dilihat dari persentase terbesar yaitu diperoleh kategori rendah sebesar $57,59 \%$. Untuk kategori sedang memperoleh nilai persentase sebesar $41,58 \%$ sedangkan untuk kategori tinggi hanya memperoleh persentase sebesar $0,83 \%$. Dapat dikatakan bahwa secara keseluruhan dari perolehan nilai siswa untuk TPDM yang dilakukan tergolong kategori rendah karena memiliki persentase terbesar dibandingkan dengan kategori sedang dan tinggi.

\section{Pembahasan}

Berdasarkan uraian analisis secara deskripsi diketahui bahwa untuk nilai minimum hasil Tes Pengetahuan Dasar Matematika siswa SMP Negeri 1 Napabalano masih berada pada kategori rendah, begitu pula jika dipilah tipa jenjang kelasnya dari kelas VII sampai kelas IX tetap berada dalam kategori rendah. Melihat nilai minimum untuk tiap masing-masing kelas pada setiap jenjangnya tidak terdapat kelas yang memiliki nilai minimum yang tidak berada dalam kategori rendah, artinya semua kelas yang ada baik itu dari kelas VII hingga kelas IX memiliki minimum berada dalam ketegori rendah. Jika melihat nilai maksimum hasil Tes Pengetahuan Dasar Matematika secara keseluruhan berada dalam kategori tinggi, begitu pula jika dipilah tipa jenjang kelasnya dari kelas VII sampai kelas IX tetap berada dalam kategori tinggi. Melihat nilai maksimum untuk tiap masing-masing kelas pada setiap jenjangnya cukup bervariasi ada yang berada dalam kategori sedang dan ada yang berada dalam kategori.

Rata-rata nilai Tes Pengetahuan Dasar Matematika siswa SMP Negeri 1 Napabalano sebesar 55,23. Jika dikaitkan dengan nilai median dan modus, maka nilai rata-rata sebesar 55,23 lebih kecil dari nilai median yaitu 56, dan nilai median lebih besar dari nilai modus sebesar 48. Begitupun nilai rata-rata hasil Tes Pengetahuan Dasar Matematika untuk tiap jenjang kelasnya memiliki rata-rata dengan rincian; rata-rata hasil Tes Pengetahuan Dasar Matematika siswa kelas VII sebesar 54,28. Jika dikaitkan dengan nilai median dan modus, maka nilai rata-rata lebih besar dari nilai median yaitu 52 dan nilai median lebih besar dari nilai modus sebesar 48, maka pada kurva distribusi frekuensi, nilai rata-rata akan terletak di sebelah kanan, sedangkan median terletak di tengahnya dan modus di sebelah kiri. Kurva distribusi frekuensi yang terbentuk adalah mencengkanan atau kemencengan positif. Rata-rata hasil Tes Pengetahuan Dasar Matematika siswa kelas VIII sebesar 56,65, jika dikaitkan dengan nilai median dan modus, maka nilai rata-rata lebih kecil dari nilai median yaitu 60 dan nilai median lebih besar dari nilai modus sebesar 40. Ratarata hasil Tes Pengetahuan Dasar Matematika siswa kelas IX sebesar 54,75 Jika dikaitkan dengan nilai median dan modus, maka nilai ratarata lebih kecil dari nilai median yaitu 56 dan nilai median sama dengan nilai modus.

Berdasarkan uraian deskripsi pada standar deviasi bahwa jika dilihat secara jenjang kelasnya antara kelas VII, kelas VIII dan kelas IX memiliki nilai standar deviasi yang tidak jauh berbeda artinya penyebaran datanya untuk tiap jenjangnya hampir sama. Nilai standar deviasi yang terbesar diantara kelas VII, VIII dan IX adalah diperoleh kelas VIII sebesar 12,38, artinya variasi data untuk kelas VIII semakin rentang dari nilai rata-rata dibandingkan dengan variasi data pada kelas VII dan IX. Jika melihat standar deviasi tiap masing-masing kelas dimulai dari kelas VII memiliki nilai standar deviasi yang beragam tiap kelasnya. Diantara kelas VII A sampai kelas VII F yang memiliki nilai standar deviasi paling tinggi adalah kelas VII E sebesar 14,24 artinya variasi data untuk kelas VII E semakin rentang dari nilai rata-rata dibandingkan dengan variasi data pada kelas VII lain. Sedangkan untuk nilai standar deviasi paling kecil yaitu kelas VII B sebesar 8,6, artinya variasi datanya semakin mendekati nilai rata-rata dari kelas tersebut. Untuk kelas VIII memiliki nilai standar deviasi yang hampir sama atau tidak jauh berbeda tiap kelasnya. Diantara kelas VIII A sampai kelas VIII G yang memiliki nilai standar deviasi paling tinggi adalah kelas VIII D sebesar 13,68 artinya variasi data untuk kelas VIII D semakin rentang dari nilai rata-rata dibandingkan dengan variasi data pada kelas VIII lain. Sedangkan untuk nilai standar deviasi paling kecil yaitu kelas VIII G sebesar 11,48, artinya variasi datanya semakin mendekati nilai rata-rata dari kelas tersebut. Untuk kelas IX memiliki nilai standar deviasi yang beragam tiap 
kelasnya. Diantara kelas IX A sampai kelas IX $\mathrm{G}$ yang memiliki nilai standar deviasi paling tinggi adalah kelas IX G sebesar 12,42 artinya variasi data untuk kelas IX G semakin rentang dari nilai rata-rata dibandingkan dengan variasi data pada kelas IX lain. Sedangkan untuk nilai standar deviasi paling kecil yaitu kelas IX B sebesar 7,42, artinya variasi datanya semakin mendekati nilai rata-rata dari kelas tersebut.

Karena varians adalah ukuran keberagaman data, sehingga semakin besar angka varians maka semakin beragamlah data yang kita miliki dan semakin kecil nilai varians yang kita miliki maka semakin homogenlah data yang kita miliki. Berdasarkan uraian deskripsi pada varians bahwa memiliki varians yang beragam untuk tiap jenjang kelasnya, dapat dilihat bahwa antara kelas VII, VII dan IX yang memiliki nilai varians paling tinggi adalah kelas VIII sebesar 153,33 sehingga dapat dikatakan data yang ada pada kelas VIII beragam. Sedangkan nilai varians yang paling kecil adalah kelas IX sebesar 116,11 dapat dikatakan data yang dimiliki pada kelas IX lebih homogen dibandingkan kelas VII dan kelas VIII. Jika melihat nilai varians tiap masing-masing kelas dimulai dari kelas VII memiliki nilai varians yang beragam tiap kelasnya. Diantara kelas VII A sampai kelas VII $F$ yang memiliki nilai varians tertinggi adalah kelas VII E sebesar 202,67, artinya data yang dimiliki kelas VII E lebih beragaman daripada data yang ada pada kelas VII yang lain. Sedangkan untuk nilai varians yang paling rendah yaitu kelas VII B sebesar 73,9, artinya data yang dimiliki kelas VII B lebih homogen dibandingkan dengan kelas VII yang lain. Untuk kelas VIII memiliki nilai varians yang beragam tiap kelasnya diantara kelas VIII A sampai kelas VIII G yang memiliki nilai varians tertinggi adalah kelas VIII D sebesar 187,13 , artinya data yang dimiliki kelas VIII D lebih beragaman daripada data yang ada pada kelas VIII yang lain. Sedangkan untuk nilai varians yang paling rendah yaitu kelas VIII G sebesar 132,02, artinya data yang dimiliki kelas VII B lebih homogen dibandingkan dengan kelas VIII yang lain. Untuk kelas IX memiliki nilai varians yang beragam tiap kelasnya diantara kelas IX A sampai kelas IX G yang memiliki nilai varians tertinggi adalah kelas IX G sebesar 154,18, artinya data yang dimiliki kelas IX G lebih beragaman daripada data yang ada pada kelas IX yang lain. Sedangkan untuk nilai varians yang paling rendah yaitu kelas IX B sebesar 55,09, artinya data yang dimiliki kelas IX B lebih homogen dibandingkan dengan kelas IX yang lain.

Berdasarkan pembahasan standar deviasi dan varians dapat dikatakan saling berkaitan atau berhubungan karena jika nilai standar deviasi tinggi maka nilai variansnya juga tinggi, artinya jika kelas yang memiliki nilai standar deviasinya tinggi maka kelas tersebut akan memilik varians tinggi pula. Berdasarkan uraian analisis secara deskriptif diketahui bahwa untuk kategori soal C1 sampai C6 secara keseluruhan hasil Tes Pengertahuan Dasar Matematika siswa SMP Negeri 1 Napabalano pada kategori C6 memiliki Persentase terendah dibanding dengan kategori soal yang lain. Dari 481 siswa yang mengikuti Tes Pengetahuan Dasar Matematika dengan jumlah soal 25 nomor dan 3 diantaranya kategori soal C6 yang jumlah jawaban benar yang diperoleh sebanyak 194 benar, dapat dikatakan kategori soal untuk C6 tergolong sulit bagi para siswa di SMP Negeri 1 Napabalano. Begitu pula dengan kategori soal C5 perolehan nilai benar secara keseluruhan dari 3 nomor soal yang diberikan yaitu sebanyak 312 benar, dan dari kategori C5 dan C6 ini dapat dikatakan bahwa ada diantara siswa yang bahkan tidak dapat menjawab 1 jawaban benar yang berkaitan dengan kategori soal C5 dan C6, sehingga dapat dikatakan bahwa soal C5 dan C6 termasuk kategori sulit atau susah bagi siswa SMP Negeri 1 Napabalano. Berbanding terbalik dengan kategori soal $\mathrm{C} 1$ dan $\mathrm{C} 2$ yang mempunyai jumlah soal sama dengan $\mathrm{C} 5$ dan $\mathrm{C} 6$ yaitu $\mathrm{C} 1, \mathrm{C} 2$ sebanyak 6 soal dan C5, C6 sebanyak 6 soal dari 25 soal Tes Pengetahuan Dasar Matematika yang diberikan hanya saja pada perolehan benar pada $\mathrm{C} 1$ dan $\mathrm{C} 2$ lebih banyak dibandingkan C5 dan C6. Pada soal C1 dan $\mathrm{C} 2$ masih tergolong cukup mudah bagi kebanyakan siswa di SMP Negeri 1 Napabalano.

Pada kategori soal $\mathrm{C} 1$ dan $\mathrm{C} 2$ memliki jumlah jawaban benar yaitu berturut-turut sebanyak 1.366 benar dan 1.047 jika dirataratakan peroleh benar pada soal $\mathrm{C} 1$ siswa dapat menjawab 2 sampai 3 soal dari 3 soal $\mathrm{C} 1$ dapat dikatakan hampir semua siswa dapat menjawab soal $\mathrm{C} 1$, begitu pula pada $\mathrm{C} 2$ ada sebagian besar siswa dapat menjawab soal $\mathrm{C} 2$, sehingga dapat dapat dikatakan bahwa soal $\mathrm{C} 1$ dan $\mathrm{C} 2$ tergolong kategori mudah bagi siswa SMP Negeri 1 Napabalano. Sedangkan pada kategori soal C3 dan C4 yang memiliki jumlah soal 
terbanyak dari 25 soal yang diberikan yaitu berturut-turut 9 soal dan 4 soal serta memiliki jumlah peroleh terbanyak yaitu di kategori soal C3 sebanyak 2324 jawaban benar dari 481 siswa yang melaksanakan tes sehingga dapat dikatakan rata-rata siswa dapat menjawab 4 sampai 5 soal dari 9 soal C3 yang diberikan. Sedangkan pada kategori soal $\mathrm{C} 4$ siswa rata-rata dapat menjawab 2 sampai 3 soal dari 4 soal $\mathrm{C} 4$ yang diberikan. Sehingga dapat dapat dikatakan bahwa soal C3 dan C4 tergolong kategori sedang bagi siswa SMP Negeri 1 Napabalano karena rata-rata siswa bisa menjawab setengah dari kategori soal yang diberikan.

Jika dilihat dari tiap jenjang kelasnya untuk tiap kategori soal yang diberikan dimulai dari kelas VII bahwa untuk kategori soal $\mathrm{C} 1$ sampai C6 secara keseluruhan hasil Tes Pengertahuan Dasar Matematika siswa kelas VII SMP Negeri 1 Napabalano pada kategori C6 memiliki Persentase terendah dibanding dengan kategori soal yang lain. Dari 156 siswa kelas VII yang mengikuti Tes Pengetahuan Dasar Matematika kategori soal C6 jumlah jawaban benar yang diperoleh sebanyak 47 benar, dapat dikatakan kategori soal untuk C6 tergolong sulit bagi para siswa kelas VII di SMP Negeri 1 Napabalano. Begitu pula dengan kategori soal C5 perolehan nilai benar secara keseluruhan yaitu sebanyak 83 benar, dan dari kategori C5 dan C6 ini dapat dikatakan bahwa ada diantara siswa yang bahkan tidak dapat menjawab 1 jawaban benar yang berkaitan dengan kategori soal C5 dan C6, sehingga dapat dikatakan bahwa soal C5 dan C6 termasuk kategori sulit atau susah bagi siswa kelas VII SMP Negeri 1 Napabalano. Jika dilihat tiap kelas VII ada kelas yang tidak dapat menjawab 1 jawaban benar yang soal C6 yaitu kelas VII A walaupun ada yang memperoleh nilai tertinggi dikelasnya dengan nilai 72 tetap belom bisa menjawab soal C6. Sedangkan untuk C5 ada siswa yang dapat menjawab 1 dari 3 soal yang diberikan walaupun jika dilihat nilai yang diperoleh cukup rendah tetapi tidak menjamin bahwa siswa tersebut tidak dapat menjawab soal yang diberikan.

Berdasarkan perolehan nilai benar terbanyak C5 dan C6 diantara kelas VII yaitu ada pada kelas VII C yang masing-masing memperoleh nilai terbanyak yaitu 37 benar untuk soal C5 dan 22 benar untuk soal C6. Dapat dikatakan bahwa pemahaman tentang soal
C5 dan C6 kelas VII C lebih baik dibandingkan dengan kelas VII yang lain berdasarkan data perolehan nilai benarnya. Sehingga jika dilihat peroleh nilai maksimum pada kelas VII yaitu 88 ada pada kelas VII C tersebut dan dapat menjawab semua soal C5 dan 1 soal benar pada C6.

Pada kategori soal $\mathrm{C} 1$ dan $\mathrm{C} 2$ memliki jumlah jawaban benar yaitu berturut-turut sebanyak 436 benar dan 336 jika dirata-ratakan peroleh benar pada soal C1 siswa dapat menjawab 2 sampai 3 soal dari 3 soal $\mathrm{C} 1$ dapat dikatakan hampir semua siswa kelas VII dapat menjawab soal $\mathrm{C} 1$, begitu pula pada $\mathrm{C} 2$ ada sebagian besar siswa kelas VII dapat menjawab soal C2, sehingga dapat dapat dikatakan bahwa soal $\mathrm{C} 1$ dan $\mathrm{C} 2$ tergolong kategori mudah bagi siswa kelas VII SMP Negeri 1 Napabalano. Sedangkan pada kategori soal C3 sebanyak 805 jawaban benar dari 156 siswa kelas VII yang melaksanakan tes sehingga dapat dikatakan ratarata siswa dapat menjawab 5 soal dari 9 soal C3 yang diberikan. Sedangkan pada kategori soal C4 dengan jumlah nilai benar yaitu 411 siswa rata-rata dapat menjawab 2 sampai 3 soal dari 4 soal C4 yang diberikan. Sehingga dapat dapat dikatakan bahwa soal C3 dan $\mathrm{C} 4$ tergolong kategori sedang bagi siswa VII SMP Negeri 1 Napabalano karena rata-rata siswa bisa menjawab setengah dari kategori soal yang diberikan.

Pada kelas VIII bahwa untuk kategori soal C1 sampai C6 secara keseluruhan hasil Tes Pengertahuan Dasar Matematika siswa kelas VIII SMP Negeri 1 Napabalano pada kategori C6 memiliki Persentase terendah dibanding dengan kategori soal yang lain. Dari 160 siswa kelas VIII yang mengikuti Tes Pengetahuan Dasar Matematika kategori soal C6 jumlah jawaban benar yang diperoleh sebanyak 81 benar, dan jumlah ini lebih banyak dibandingkan kelas VII dapat dikatakan kategori soal untuk C6 tergolong sulit bagi para siswa kelas VIII di SMP Negeri 1 Napabalano, untuk rata-rata benarnya ada yang bahkan tidak dapat menjawab 1 soal benar dari 3 soal C6. Untuk kategori soal C5 perolehan nilai benar secara keseluruhan yaitu sebanyak 128 benar kalau dirata-ratakan hampir semua siswa dapat menjawab 1 jawaban benar dari 3 soal $\mathrm{C}$, sehingga dapat dikatakan bahwa soal C5 dan C6 termasuk kategori sulit atau susah bagi siswa kelas VIII SMP Negeri 1 Napabalano. Jika 
dilihat tiap kelas VIII ada kelas yang memiliki jumlah benar yang relatif banyak dibandingkan kelas VIII lainnya yaitu kelas VIII A, dengan jumlah benar C5 sebanyak 35 dan C6 21. Jika melihat banyak siswa kelas VIII A yang mengikuti tes yaitu 22 bisa dikatakan $\mathrm{C} 5$ ratarata benarnya siswa bisa menjawab minimal 1 soal C5, sama halnya dengan C6 hampir semua siswa dapat menjwab 1 soal benar C6. Dapat dikatakan bahwa pemahaman tentang soal C5 dan C6 kelas VIII A lebih baik dibandingkan dengan kelas VIII yang lain berdasarkan data perolehan nilai benarnya.

Pada kategori soal $\mathrm{C} 1$ dan $\mathrm{C} 2$ memliki jumlah jawaban benar yaitu berturut-turut sebanyak 460 benar dan 354 jika dirata-ratakan peroleh benar pada soal $\mathrm{C} 1$ siswa dapat menjawab 2 sampai 3 soal dari 3 soal C1 dapat dikatakan hampir semua siswa kelas VIII dapat menjawab soal $\mathrm{C} 1$, begitu pula pada $\mathrm{C} 2$ ada sebagian besar siswa kelas VIII dapat menjawab soal C2, sehingga dapat dapat dikatakan bahwa soal $\mathrm{C} 1$ dan $\mathrm{C} 2$ tergolong kategori mudah bagi siswa kelas VIII SMP Negeri 1 Napabalano. Sedangkan pada kategori soal C3 sebanyak 750 jawaban benar dari 160 siswa kelas VIII yang melaksanakan tes, jumlah ini justru lebih kecil dibanding kelas VII sehingga dapat dikatakan rata-rata siswa dapat menjawab 4 soal dari 9 soal C3 yang diberikan. Sedangkan pada kategori soal C4 dengan jumlah nilai benar yaitu 497 siswa rata-rata dapat menjawab 3 soal dari 4 soal C4 yang diberikan. Sehingga dapat dapat dikatakan bahwa soal C3 dan C4 tergolong kategori sedang bagi siswa VIII SMP Negeri 1 Napabalano karena rata-rata siswa bisa menjawab setengah dari kategori soal yang diberikan.

Pada kelas IX bahwa untuk kategori soal C1 sampai C6 secara keseluruhan hasil Tes Pengertahuan Dasar Matematika siswa kelas IX SMP Negeri 1 Napabalano pada kategori C6 memiliki Persentase terendah dibanding dengan kategori soal yang lain. Dari 165 siswa kelas IX yang mengikuti Tes Pengetahuan Dasar Matematika kategori soal C6 jumlah jawaban benar yang diperoleh sebanyak 66 benar, artinya sebagian besar siswa bahkan tidak dapat menjwab 1 jawaban benar soal C6, dapat dikatakan kategori soal untuk C6 tergolong sulit bagi para siswa kelas IX di SMP Negeri 1 Napabalano. Untuk kategori soal C5 perolehan nilai benar secara keseluruhan yaitu sebanyak 101 benar kalau dirata-ratakan ada beberapa siswa dapat menjawab 1 jawaban benar dari 3 soal C5, sehingga dapat dikatakan bahwa soal C5 dan C6 termasuk kategori sulit atau susah bagi siswa kelas IX SMP Negeri 1 Napabalano. Jika dilihat tiap kelas IX ada kelas yang memiliki jumlah benar yang relatif banyak dibandingkan kelas IX lainnya yaitu kelas IX A, dengan jumlah benar C5 sebanyak 21 dan C6 26. Jika melihat banyak siswa kelas VIII A yang mengikuti tes yaitu 24 bisa dikatakan C5 ratarata benarnya hampir siswa bisa menjawab minimal 1 soal C5, sama halnya dengan C6 ratarata benarnya semua siswa dapat menjwab 1 soal benar C6. Dapat dikatakan bahwa pemahaman tentang soal C5 dan C6 kelas IX A lebih baik dibandingkan dengan kelas IX yang lain berdasarkan data perolehan nilai benarnya. Jika melihat nilai maksimum untuk kelas IX sebesar 92 dan nilai tersebut terdapat dikelas IX A yang memiliki jawaban benar masing-masing C5 dan C6 sebanyak 2 soal, dan merujuk pada nilai minimum kelas IX yaitu sebesar 20 ada dikelas IX G yang memilik jawaban benar C5 dan C6 sebanyak 1 soal sehingga dapat dikatakan tidak hanya yang memperoleh nilai tinggi saja yang dapat menjawab soal C5 dan C6.

Pada kategori soal $\mathrm{C} 1$ dan $\mathrm{C} 2$ memliki jumlah jawaban benar yaitu berturut-turut sebanyak 470 benar dan 357 jika dirata-ratakan peroleh benar pada soal C1 siswa dapat menjawab 2 sampai 3 soal dari 3 soal C1 dapat dikatakan hampir semua siswa kelas IX dapat menjawab soal $\mathrm{C} 1$, begitu pula pada $\mathrm{C} 2$ ada sebagian besar siswa kelas IX dapat menjawab soal C2, sehingga dapat dapat dikatakan bahwa soal $\mathrm{C} 1$ dan $\mathrm{C} 2$ tergolong kategori mudah bagi siswa kelas IX SMP Negeri 1 Napabalano. Sedangkan pada kategori soal C3 sebanyak 769 jawaban benar dari 165 siswa kelas IX yang melaksanakan tes, sehingga dapat dikatakan rata-rata siswa dapat menjawab 5 soal dari 9 soal C3 yang diberikan. Sedangkan pada kategori soal C4 dengan jumlah nilai benar yaitu 497 siswa rata-rata dapat menjawab 3 soal dari 4 soal C4 yang diberikan. Sehingga dapat dapat dikatakan bahwa soal C3 dan C4 tergolong kategori sedang bagi siswa IX SMP Negeri 1 Napabalano karena rata-rata siswa bisa menjawab setengah dari kategori soal yang diberikan.

Berdasarkan hasil pemerikasaan jawaban siswa dari Tes Pengetahuan Dasar Matematika siswa SMP Negeri 1 Napabalano 
siswa cenderung salah pada soal nomor 10,11 , $14,19,21,22,23,24$ dan 25. Soal yang salah termasuk kategori soal tentang C3, C5 dan C6 dimana dari kategori soal tersebut dianggap susah untuk siswa. Karena untuk soal C5 dan C6 butuh pemahaman apalagi soal yang diberikan untuk kategori C5 dan C6 tersebut menggunakan soal cerita. Sedangkan untuk kategori soal tentang $\mathrm{C} 1, \mathrm{C} 2$ masih dianggap cukup mudah dan bisa dipahami oleh siswa. Karena untuk level $\mathrm{C} 1$ dan C2 masuk kategori siswa yang level ke bawah atau rendah dalam hal belajar, untuk level $\mathrm{C} 3$ dan $\mathrm{C} 4$ masuk kategori siswa yang level sedang atau menengah dalam hal belajar dan untuk level C5 dan C6 masuk kategori yang bisa dibilang tinggi.

Secara keseluruhan persentase nilai perolehan siswa hasil Tes Pengetahuan Dasar Matematika tergolong kategori rendah karena memiliki persentase pada ketegori rendah lebih besar dibandingkan dengan kategori sedang dan tinggi. Sama halnya jika dilihat berdasarkan tiap jenjangnya yaitu untuk persentase perolehan nilai kelas VII tergolong kategori rendah karena memiliki persentase pada ketegori rendah lebih besar dibandingkan dengan kategori sedang dan tinggi. Persentase perolehan nilai kelas VIII tergolong kategori sedang karena memiliki persentase pada ketegori sedang lebih besar dibandingkan dengan kategori rendah dan tinggi. Persentase perolehan nilai kelas IX tergolong kategori rendah karena memiliki persentase pada ketegori rendah lebih besar dibandingkan dengan kategori sedang dan tinggi.

Hasil Tes Pengetahuan Dasar Matematika siswa SMP Negeri 1 Napabalano pada jenjang tiap kelasnya yaitu kelas VII, Kelas VIII dan kelas IX belum memberikan hasil yang memuaskan. Hal ini merujuk pada hasil rata-rata setiap jenjang kelas di SMP Negeri 1 Napabalano pada lampiran E jelas terlihat baik itu nilai minumum dan maksimum siswa, nilai rata-rata siswa, nilai modus (frekuensi nilai yang sering muncul) dan standar deviasinya.

Materi yang digunakan dalam pembuatan soal Tes Pengetahuan dasar Matematika siswa SMP Negeri 1 Napabalano dengan model soal pilihan ganda yaitu materi tentang operasi hitung bilangan bulat, KPK dan FPB serta pecahan. Melihat hasil kerja siswa untuk soal-soal Tes Pengetahuan Dasar Matematika siswa SMP Negeri 1 Napabalano untuk keseluruhan cenderung rendah pada materi operasi hitung bilangan bulat, pecahan dan FPB. Dari hasil pekerjaan siswa yang telah diperiksa kebanyakan siswa bingung pengerjaan operasi hitung bilangan bulat yang menggabungkan bilangan bulat positif dan bilangan bulat negatif dalam 1 model soal. Siswa kebanyakan belum tau proses pekerjaan operasi bilangan bulat positif dan bilangan bulat tersebut. Apalagi siswa dijumpai dengan operasi hitung campuran bilangan bulat gabungan antara operasi penjumlahan, pengurangan, perkalian dan pembagian dalam 1 soal. Siswa belum memahami operasi yang harus dikerjakan terlebih dahulu ketika menjumpai soal seperti operasi hitung campuran bilangan bulat. Dari hasil Tes Pengetahuan Dasar Matematika siswa SMP Negeri 1 Napabalano yang didapatkan dijumpai soal tentang operasi hitung campuran bilangan bulat dengan mengunakan keempat operasi hitung siswa kebanyakan tidak memandang bentuk operasinya, siswa menyelesaikan sesuai urutan pada soal tersebut sehingga membuat hasil pekerjaannya salah.

Pada materi pecahan juga siswa kurang memahami proses pekerjaannya yang lebih dulu dikerjakan jika menjumpai soal pecahan yang ada operasi penjumlahan, pengurangan, perkalian dan pembagian dalam 1 soal. Walaupun dari soal yang diberikan sederhana tetapi ketika soal pecahan tersebut memiliki penyebut yang berbeda menjadi faktor siswa tidak dapat menyelesaikan soal tersebut dengan benar. Dari hasil Tes Pengetahuan Dasar Matematika siswa SMP Negeri 1 Napabalano yang didapatkan dijumpai soal dengan model pecahan yang berpenyebut berbeda dengan operasi campuran khususnya ada penjumlahan dan perkalian siswa cenderung keliru yang mana terlebih dahulu yang kerjakan, dan sering kali siswa tidak menyamakan penyebutnya dengan model soal penjumlahan dan pengurangan pecahan.

Pada materi KPK dan FPB juga siswa kurang memahami proses pekerjaannya. Dari hasil Tes Pengetahuan Dasar Matematika siswa SMP Negeri 1 Napabalano yang didapatkan siswa terkadang keliru membedakan yang mana dikatakan KPK dan yang mana dikatakan FPB. Terkhusus pada FPB siswa cenderung keliru jika mendapat soal dengan mencari dua nilai yang diberikan menentukan FPBnya dimana nilai soal tersebut salah satu nilainya bisa menjadi 
FPBnya tetapi kebanyakan siswa tidak melihat itu. Terutama di dalam soal Tes Pengetahuan Dasar Matematika yang diberikan ada soal yang serupa dengan penjelasan tersebut yaitu pada nomor 10 yang membuat kebanyakan siswa keliru.

Deskripsi untuk masing-masing jenjang kelas melihat hasil kerja Tes Pengetahuan Dasar Matematika siswa SMP Negeri 1 Napabalano pada kelas VII, kelas VIII dan kelas IX. Pada kelas VII untuk hasil Tes Pengetahuan Dasar Matematika memiliki nilai yang kurang bagus terutama pada materi pecahan, KPK dan FPB. Untuk materi operasi campuran bilangan bulat siswa banyak menjawab dengan benar dibandingkan soal tentang pecahan, KPK dan FPB. Pada kelas VIII untuk hasil Tes Pengetahuan Dasar Matematika memiliki nilai yang kurang bagus terutama pada materi operasi hitung campuran bilangan bulat, pecahan dan FPB. Untuk materi KPK siswa banyak menjawab dengan benar dibandingkan soal tentang operasi hitung campuran bilangan bulat, pecahan dan FPB. Pada kelas VII untuk hasil Tes Pengetahuan Dasar Matematika memiliki nilai yang kurang bagus terutama pada materi pecahan dan FPB. Untuk materi operasi campuran bilangan bulat siswa banyak menjawab dengan benar dibandingkan soal tentang pecahan dan FPB.

Adapun faktor-faktor yang bisa dianggap menjadi menyebabkan rendahnya hasil Tes Pengetahuan Dasar Matematika siswa SMP Negeri 1 napabalano adalah kurangnya antusias siswa mengerjakan soal Tes Pengetahuan Dasar Matematika yang diberikan. Cenderung malas mengerjakan soal dengan serius mangingat soal yang diberikan berupa pilihan ganda sehingga membuat siswa asal jawab pada pilihan yang dicantumkan. Kurangnya pengetahuan siswa pada materi yang ada kaitanya dengan soal yang diberikan. Karena melihat hasil pekerjaan siswa yang didapat dengan lembar cakaran siswa masih terbilang kurang memehami materi yang diberikan karena kebanyakan cakaran yang diberikan cenderung kosong atau tidak sesuai materi tes yang ada.

\section{Simpulan dan Saran}

\section{Simpulan}

Berdasarkan hasil penelitian dan
pembahasan yang telah dikemukakan

sebelumnya, maka dapat ditarik kesimpulan sebagai berikut:

1. Rata-rata hasil TPDM siswa SMP Negeri 1 Napabalano yaitu sebesar 55,23 dengan median sebesar 56, nilai modus sebesar 56 dan nilai standar deviasinya sebesar 11,52 serta varians sebesar 132,78. Rata-rata hasil TPDM untuk siswa VII sebesar 54,28 dengan median sebesar 52, nilai modus sebesar 48 dan nilai standar deviasinya sebesar 11,31 serta varians sebesar 127,82. Rata-rata hasil TPDM untuk siswa kelas VIII sebesar 56,65 dengan median sebesar 60 , nilai modus sebesar 40 dan nilai standar deviasinya sebesar 12,38 serta varians sebesar 153,33. Rata-rata hasil TPDM untuk siswa kelas IX sebesar 54,57 dengan median sebesar 56, nilai modus sebesar 56 dan nilai standar deviasinya sebesar 10,78 serta varians sebesar 116,11.

2. Rata-rata hasil TPDM siswa SMP Negeri 1 Napabalano yaitu sebesar 55,23 dengan median sebesar 56, nilai modus sebesar 56 dan nilai standar deviasinya sebesar 11,52 serta varians sebesar 132,78 . Rata-rata hasil TPDM untuk siswa VII sebesar 54,28 dengan median sebesar 52, nilai modus sebesar 48 dan nilai standar deviasinya sebesar 11,31 serta varians sebesar 127,82. Rata-rata hasil TPDM untuk siswa kelas VIII sebesar 56,65 dengan median sebesar 60 , nilai modus sebesar 40 dan nilai standar deviasinya sebesar 12,38 serta varians sebesar 153,33. Rata-rata hasil TPDM untuk siswa kelas IX sebesar 54,57 dengan median sebesar 56, nilai modus sebesar 56 dan nilai standar deviasinya sebesar 10,78 serta varians sebesar 116,11.

3. Rata-rata hasil TPDM siswa SMP Negeri 1 Napabalano yaitu sebesar 55,23 dengan median sebesar 56, nilai modus sebesar 56 dan nilai standar deviasinya sebesar 11,52 serta varians sebesar 132,78 . Rata-rata hasil TPDM untuk siswa VII sebesar 54,28 dengan median sebesar 52, nilai modus sebesar 48 dan nilai standar deviasinya sebesar 11,31 serta varians sebesar 127,82. Rata-rata hasil TPDM untuk siswa kelas VIII sebesar 56,65 dengan median sebesar 60 , nilai modus sebesar 40 dan nilai standar deviasinya sebesar 12,38 serta varians sebesar 153,33. Rata-rata hasil TPDM untuk siswa kelas IX sebesar 54,57 dengan 
median sebesar 56, nilai modus sebesar 56 dan nilai standar deviasinya sebesar 10,78 serta varians sebesar 116,11.

4. Rata-rata hasil TPDM siswa SMP Negeri 1 Napabalano yaitu sebesar 55,23 dengan median sebesar 56, nilai modus sebesar 56 dan nilai standar deviasinya sebesar 11,52 serta varians sebesar 132,78. Rata-rata hasil TPDM untuk siswa VII sebesar 54,28 dengan median sebesar 52, nilai modus sebesar 48 dan nilai standar deviasinya sebesar 11,31 serta varians sebesar 127,82. Rata-rata hasil TPDM untuk siswa kelas VIII sebesar 56,65 dengan median sebesar 60 , nilai modus sebesar 40 dan nilai standar deviasinya sebesar 12,38 serta varians sebesar 153,33. Rata-rata hasil TPDM untuk siswa kelas IX sebesar 54,57 dengan median sebesar 56, nilai modus sebesar 56 dan nilai standar deviasinya sebesar 10,78 serta varians sebesar 116,11.

Saran

Berdasarkan kesimpulan di atas, saran yang dapat diberikan adalah pertama; guru hendaknya meninjau kembali materimateri pengetahuan dasar matematika siswa yang masih dianggap susah bagi siswa, kedua; sebagai sarana untuk menambah referensi dan bahan kajian dalam bidang pendidikan matematika dan untuk penelitian lanjutan mengenai deskripsi pengetahuan dasar matematika pada siswa SMP Negeri 1 Napabalano, ketiga; sebagai bahan informasi bagi pihak sekolah untuk meningkatkan mutu pendidikan khususnya pendidikan matematika dan keempat; Guru dapat menjadikan informasi dalam penelitian ini sebagai tambahan wawasan dalam mengelola pembelajaran di kelas.

\section{Daftar Pustaka}

Faticha Rizky Nur I. 2015. Pengaruh Metode Pembelajaran Kooperatif Tipe Group Investigation (GI) dan Jigsaw pada Materi Pokok Garis Singgung Lingkaran terhadap Prestasi Belajar Matematika Siswa SMP Kelas VIII.
Skripsi, diterbitkan, FMIPA Universitas Negeri Yogyakarta. Yogyakarta.

Halistin. (2014). Analisis Deskripsi Pengetahuan Dasar Matematika Siswa Kelas IX SMP Negeri se-Kota Kendari. Skripsi tidak diterbitkan, FKIP Universitas Halu Oleo. Kendari

Hasan, M. Iqbal. (2002). Pokok-Pokok Materi Metodologi Penelitian dan Aplikasinya. Bogor: Ghalia Indonesia.

Mahdaniah Hasan. (2016). Pengaruh Kombinasi Model Pembelajaran Kooperatif dan Pengetahuan Dasar Matematika terhadap Hasil Belajar Matematika Siswa Kelas X SMA Negeri 2 Kendari. Skripsi, tidak diterbitkan, FKIP Universitas Halu Oleo. Kendari.

Maonde, Faad. (2011). Aplikasi Penelitian Eksperimen dalam Bidang Pendidikan dan Sosial. Kendari: Unhalu Press.

Muliani Majja. (2016). Pengaruh Motivasi Berprestasi Melalui Kombinasi Model Pembelajaran Kooperatif terhadap Hasil Belajar Matematika (Studi Eksperimen pada Siswa Kelas VII SMP Negeri 13 Kendari). Skripsi, tidak diterbitkan, FKIP Universitas Halu Oleo. Kendari.

Nismawati. (2017). Pengaruh Model Pembelajaran ARIAS (Assurance, Relevance, Interest, Assesment, Satisfaction) terhadap Kemampuan Pemahaman Matematis Siswa Kelas VII SMP Negeri 23 Bombana. Skripsi, tidak diterbitkan, FKIP Universitas Halu Oleo. Kendari.

Soedjadi, R. (2000). Kiat Pendidikan Matematika di Indonesia. Jakarta: Dirjen Dikti Depdiknas.

Sugiyono. (2004). Metode Penelitian Bisnis. Bandung: Alfabeta.

Wawan, A dan Dewi, M. 2010. Teori dan Pengukuran Pengetahuan, Sikap dan Perilaku Manusia.Yogyakarta: Nuha Medika 